\title{
Understanding the Anatomy of the Denonvilliers Fascia: Review Article
}

\section{Compreendendo a anatomia da fáscia de Denonvilliers: Artigo de revisão}

\author{
Mohammed Yousef Alessa ${ }^{1}$ (1) \\ ${ }^{1}$ King Faisal University Surgery, Hofuf, Eastern Province, Saudi Arabia \\ Address for correspondence Mohammed Yousef Alessa, King Faisal \\ University Surgery, Hofuf, Eastern Provience, Saudi Arabia \\ J Coloproctol 2021;41(2):193-197. \\ (e-mail: medicine88@hotmail.com).
}

\section{Abstract \\ Keywords \\ - anatomy of denonvilliers fascia \\ - understanding anatomy \\ - review article \\ Resumo \\ Palavras-chave \\ - anatomia da fáscia denonvilliers \\ - compreensão da anatomia \\ - artigo de revisão}

The postoperative outcome of rectal cancer has been improved after the introduction of the principles of total mesorectal excision (TME). Total mesorectal excision includes resection of the diseased rectum and mesorectum with non-violated mesorectal fascia (en bloc resection). Dissection along the mesorectal fascia through the principle of the "holy plane" minimizes injury of the autonomic nerves and increases the chance of preserving them. It is important to stick to the TME principle to avoid perforating the tumor; violating the mesorectal fascia, thus resulting in positive circumferential resection margin (CRM); or causing injury to the autonomic nerves, especially if the tumor is located anteriorly. Therefore, identifying the anterior plane of dissection during TME is important because it is related with the autonomic nerves (Denonvilliers fascia). Although there are many articles about the Denonvilliers fascia (DVF) or the anterior dissection plane, unfortunately, there is no consensus on its embryological origin, histology, and gross anatomy. In the present review article, I aim to delineate and describe the anatomy of the DVF in more details based on a review of the literature, in order to provide insight for colorectal surgeons to better understand this anatomical feature and to provide the best care to their patients.

O resultado pós-operatório do câncer retal foi melhorado após a introdução dos princípios da excisão total do mesorreto (TME, na sigla em inglês). A excisão total do mesorreto inclui a ressecção do reto e do mesorreto afetados com fáscia mesorretal não violada (ressecção em bloco). A dissecção ao longo da fáscia mesorretal pelo princípio do "plano sagrado" minimiza a lesão dos nervos autônomos e aumenta a chance de preservá-los. É importante seguir o princípio da TME para evitar: a perfuração do tumor; a violação da fáscia mesorretal, resultando em margem de ressecção circunferencial (CRM) positiva; ou a lesão aos nervos autônomos, especialmente se o tumor estiver localizado anteriormente. Portanto, a identificação do plano anterior de dissecção durante a TME é importante, pois está relacionada com os nervos received

May 20, 2020

accepted

August 23, 2020

published online

May 24, 2021
DOI https://doi.org/

10.1055/s-0041-1724054. ISSN 2237-9363.

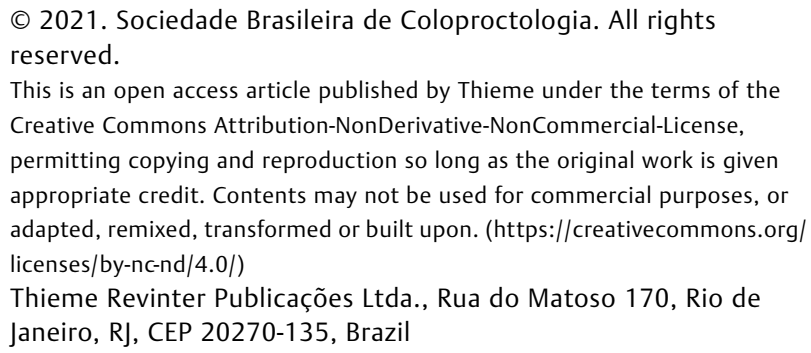

(c) 2021. Sociedade Brasileira de Coloproctologia. All rights reserved.

This is an open access article published by Thieme under the terms of the Creative Commons Attribution-NonDerivative-NonCommercial-License, permitting copying and reproduction so long as the original work is given appropriate credit. Contents may not be used for commercial purposes, or adapted, remixed, transformed or built upon. (https://creativecommons.org/ licenses/by-nc-nd/4.0/)

Thieme Revinter Publicações Ltda., Rua do Matoso 170, Rio de Janeiro, RJ, CEP 20270-135, Brazil 
autonômicos (fáscia de Denonvilliers). Embora existam muitos artigos sobre a fáscia de Denonvilliers (DVF, na sigla em inglês) ou o plano de dissecção anterior, infelizmente não há consenso sobre sua origem embriológica, histologia e anatomia macroscópica. No presente artigo de revisão, pretendo delinear e descrever a anatomia da DVF em mais detalhes com base em uma revisão da literatura, a fim de fornecer subsídios para os cirurgiões colorretais entenderem melhor esta característica anatômica e fornecer o melhor cuidado para seus pacientes.

\section{Introduction}

Colorectal surgeons can get better functional and oncological outcomes by applying the principles of total mesorectal excision (TME) and dissection through the "holy plane". ${ }^{1} \mathrm{~A}$ Dutch TME trial showed that the main cause of postoperative anorectal and urogenital dysfunction is injury to the autonomic nerves during dissection. ${ }^{2}$ For this reason, the posterior, lateral, and anterior planes of dissection were defined in TME to emphasize on identification and preservation of autonomic nerves along with en bloc resection of diseased rectum, but, unfortunately, there is no consensus about the anterior plane's, also known as Denonvilliers facia (DVF), embryological origin, anatomy, and its relationship with adjacent nerve structures. ${ }^{3}$ Mohammed Alessa mentioned that the DVF is closer to the prostate, while others said it is closer to the rectum or even more adherent to the anterior mesorectum. Because of controversy in description of the DVF, the anterior plane of dissection in TME is not clear. ${ }^{4-6}$ Some surgeons believe that dissection should be posterior to the fascia, while others propose splitting the layers of fascia, and some adopt dissection anterior to the DVF. Suboptimal surgery with poor oncological and functional outcome can result from inappropriate anterior dissection during TME secondary to confusion when identifying the anterior plane. Excellent knowledge of the complex pelvic anatomy is a prerequisite to optimize the oncological and functional outcome of rectal cancer. ${ }^{7-10}$

\section{Embryology of Denonvilliers Fascia}

Fusion between the two walls of the embryonic peritoneum of the rectovesical cul-de-sac leads to development of the DVS later on, as described by Denonvilliers initially and supported by Cuneo, while Vaeu and Zuckerkandl showed its extension to the pelvic floor. By conducting pelvic floor dissection studies on fetuses and adults, Elliot Smith confirmed the fusion theory. ${ }^{11,12}$ Later on, Wesson described that the thick mesenchymal layer over the rectum and urinary bladder differentiate into muscle and connective tissue, leading to the development of the DVF in adults. On the other hand, Tobin and Benjamin found that the layer described by Wesson developed into the fascia propria of the rectum, as identified by Denonvilliers. As a result of this controversy, the existence of two separate layers cannot be ruled out, and dissection in anterior plane becomes more confusing. Lastly, Richardson demonstrated on an electron microscope a dense double layer of elastin in the rectogenital septum, thus adding further support to the fusion theory. ${ }^{13,14}$ Although there is uncertainty about the presence of the DVF in females, Heald and Moran mentioned its importance in rectal surgery, as it provides mobility to the rectum on the posterior vaginal wall. ${ }^{15}$

\section{Anatomy of the DVF}

The DVF develops from the fusion of the two walls of the peritoneal cul-de-sac during the embryological stage, and it extends from the deepest point of the rectovesical pouch to the pelvic floor. Initially, DVF was described as a prostatoperitoneal membrane located between the rectum and the seminal vesicle, while in females, it is considered as part of the rectovaginal septum and named rectovaginal fascia. Grossly, it lies behind the vagina in females and the seminal vesicle and prostate in males. Cardinally, it is attached to the uterosacral complex in females or the rectovesical pouch in males. Laterally, it is connected to the endopelvic fascia above the levator muscle. Caudally, it is attached to the perineal body. ${ }^{16}$ Under the microscope, it is composed of collagen, smooth muscle, and elastin fibers. It has two layers that are difficult to distinguish during dissection. Cavernous nerves run in neurovascular bundles at the anterolateral border of the DVF. This bundle contains sympathetic and parasympathetic nerves, supplying the rectum and the genitourinary tract. The sympathetic nerves are responsible for urinary continence and ejaculation, while the parasympathetic nerves control micturition, erection, and lubrication. Appropriate knowledge about autonomic nerves is essential during rectal surgery to avoid nerve injury that can lead to sexual and urinary dysfunction. ${ }^{17}$ See - Figs. 1-3

\section{Clinical Implication}

It is important to review the opinion of urologists to make a comprehensive review of the DVF because of its close relationship to prostatic gland and to emphasize their technique of nerve preservation during prostatectomy. There is an important relationship between the prostate and the DVF, and, for this reason, it is important to understand the anatomy of the DVF and the autonomic nerves during prostatectomy. Hu et al. proposed the intra and interfascial nerve-preserving approach for prostatectomy. Understanding the anatomy of the DVF is essential to avoid mechanical or thermal injury to the autonomic nerves during dissection. 


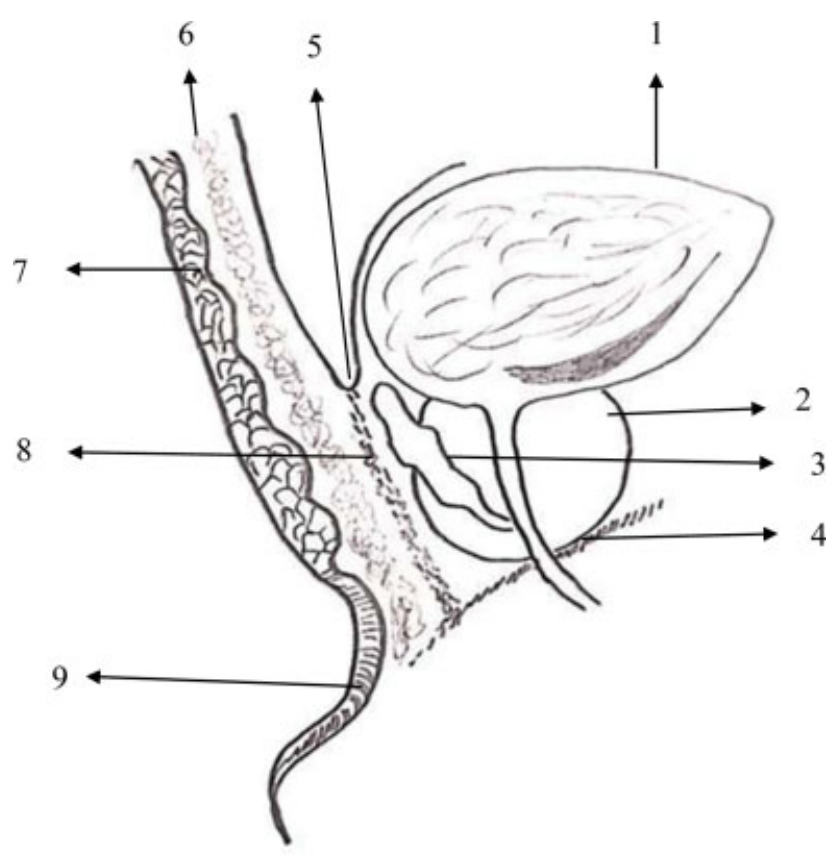

Fig. 1 Lateral aspect of the Denonvilliers fascia. 1 - Urinary bladder. 2 Prostate gland. 3 - Seminal vesicles. 4 - Pelvic floor. 5 - Rectovesical pouch. 6 - Anterior mesorectum. 7 - Anterior rectal wall. 8 - Denonvilliers fascia. 9 - Anal canal.

Endopelvic fascia consists of multiple layers of connective tissue that include the prostate and bladder, and these structures are supported by the insertion of the fascia into the pubic bone (puboprostatic ligaments). ${ }^{18,19}$ The intrafascial plane is formed by the prostatic fascia that outlines the prostatic gland and the capsule. Outside this fascia, laterally, is the levator fascia (part of the parietal fascial layer), which acts as the boundary for the interfascial plane.

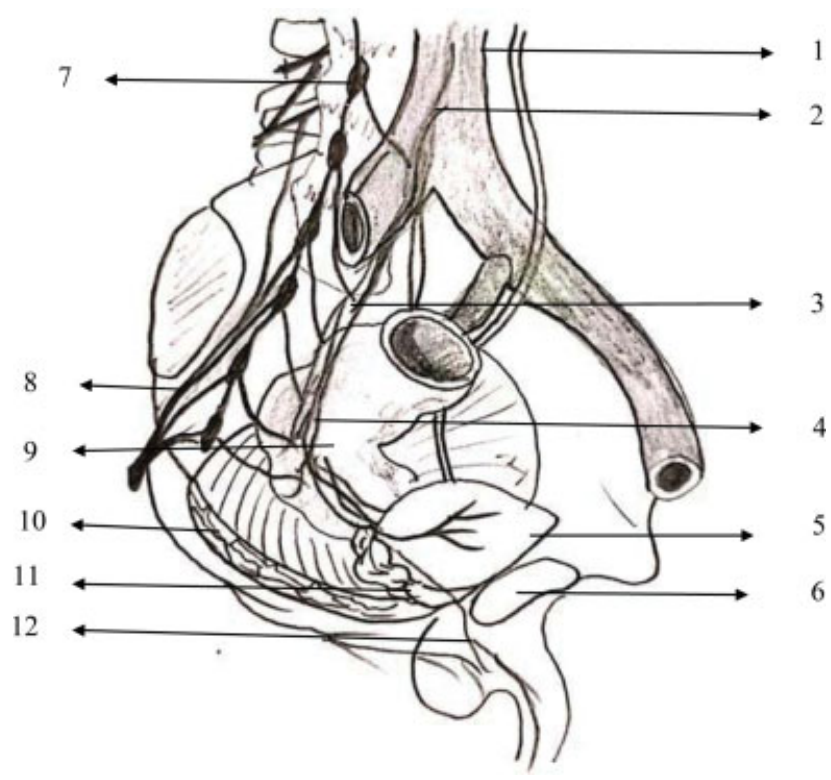

Fig. 2 Pelvic autonomic nerves. 1 - Abdominal aorta. 2 - Superior hypogastric plexus. 3 - Hypogastric nerve. 4 - Pelvic plexus. 5 - Urinary bladder. 6 - Prostate gland. 7 - Sympathetic trunk. 8 - Sacral nerves. 9 Rectum. 10 - Levator ani. 11 - Pudendal nerve. 12 - Dorsal penis nerve.

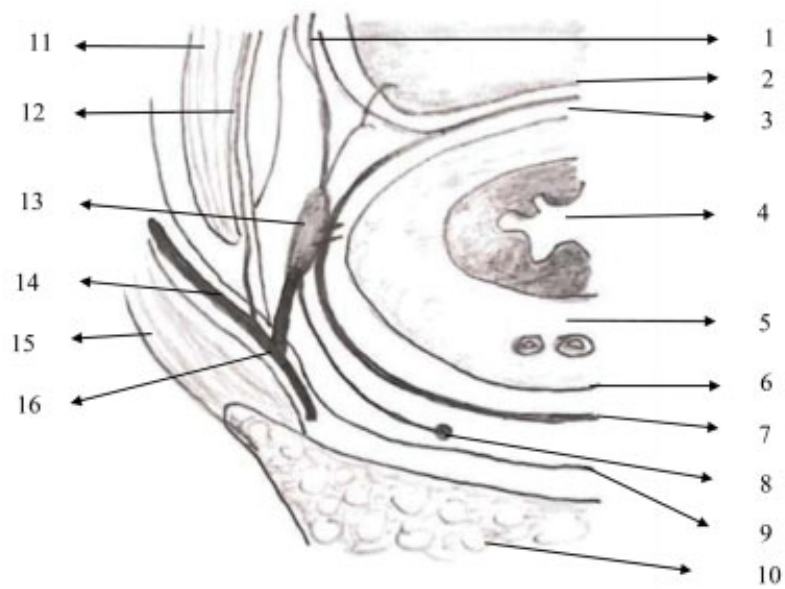

Fig. 3 Nerves around rectum. 1 - Neurovasvular bundle. 2 - Denonvilliers fascia. 3 - Rectal proper fascia. 4 - Rectum. 5 - Mesorectum. 6 Rectal proper fascia. 7 - Prehypogastric nerve fascia. 8 - Hypogastric nerve. 9 - Parietal presacral fascia. 10 -Sacrum. 11 - Levator ani muscle. 12 - Levator ani nerve. 13 - Pelvic plexus. 14 - Sacral nerve. 15 Piriformis muscle. 16 - Pelvic Splanchnic nerve.

Posteriorly, this same interfascial plane is bound by the DVF. Most of nerves run between the anterior part of the DVF and the levator fascia; for that reason, dissection in interfascial plane carries the lowest risk of nerve injury, while dissection outside this plane is associated with poor sexual and urinary function, due to nerve injury. Many surgeons prefer an interfascial dissection for a nerve sparing result without affecting oncologic outcome in selected patients. Some surgeons did not perform an intrafascial nerve-sparing operation because of the risk of positive margins, especially in T3 disease, while others showed that it is associated with improved functional and oncological outcomes. ${ }^{20,21}$

\section{See - Figs. 4-5}

Kim et al. proposed a step-by-step approach to anterior pelvic dissection in order to be able to fully understand the anatomy of the DVF, to preserve the autonomic nerves, and to minimize injury during anterior dissection for low lying rectal cancer.

\section{Anterior Pelvic Dissection}

You can start the anterior dissection with an incision to the peritoneal reflection, anteriorly. After conducting this minor dissection, you can get the appropriate plane that extends to the level of the seminal vesicle or vagina. With good assistant traction during the operation, you can identify the DVF in front of the rectum and posterior to the seminal vesicle. If the tumor is located anteriorly, dissection should be performed anterior to the DVF. ${ }^{22,23}$ In this situation, autonomic nerve injury is common, as the pelvic plexus passes inferiorly to the seminal vesicles to enter the urinary bladder. On the other hand, if the tumor is located posteriorly, dissection should proceed posteriorly to the DVF to avoid nerve injury. As dissection continues, you can create a vascular plane between the rectum, mesorectum, and neurovascular bundle to avoid injury to them. Dissection is extended laterally along 

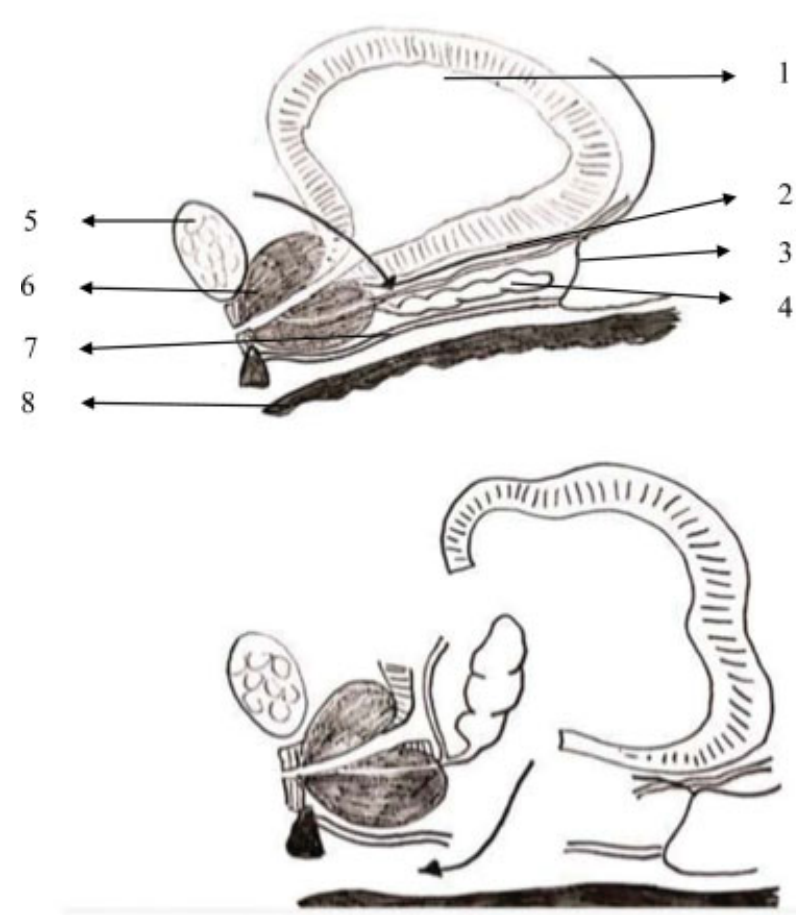

Fig. 4 Dissection of the Denonvilliers fascia. 1 - Urinary bladder. 2 - Dissection of anterior layer of Denonvilliers fascia. 3 - Pertonium. 4 - Seminal vesicle. 5 - Pubic bone. 6 - Prostate gland. 7 - Denonvilliers fascia. 8 - Rectum.

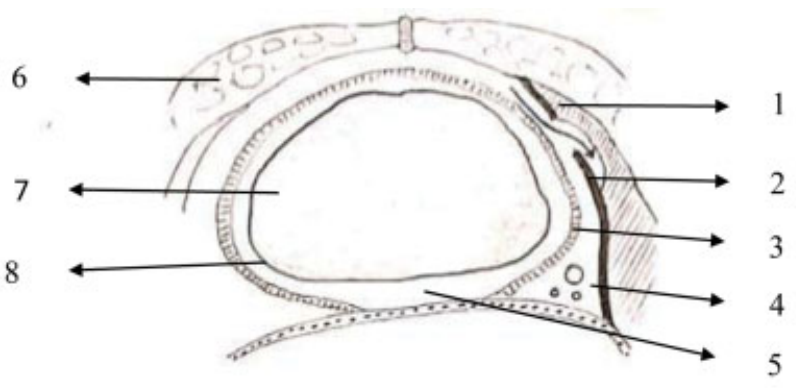

\section{Conclusion}

There is a lot of controversy about the development and anatomy of the DVF that leads to confusion about the appropriate plane of dissection during TME. The DVF arises from the fusion of the two walls of the embryological peritoneal cul-de-sac and extends from the deepest point of the rectovesical pouch to the pelvic floor. There is no consensus on the relationship between the DVF and the appropriate plane of anterior dissection for rectal cancer surgery. A good understanding of the anatomy of the pelvic

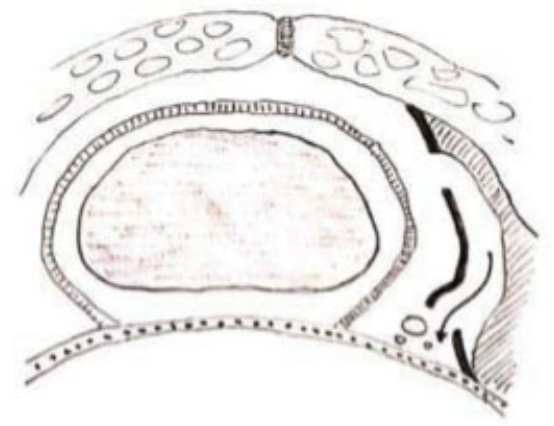

Fig. 5 Dissection of the Denonvilliers fascia. 1 - Levator ani. 2 - Endopelvic fascia. 3 - Prostatic fascia. 4 - Neurovascular bundle. 5 - Denonvilliers fascia. 6 - Pubic bone. 7 - Prostate gland. 8 - Prosatatic capsule.

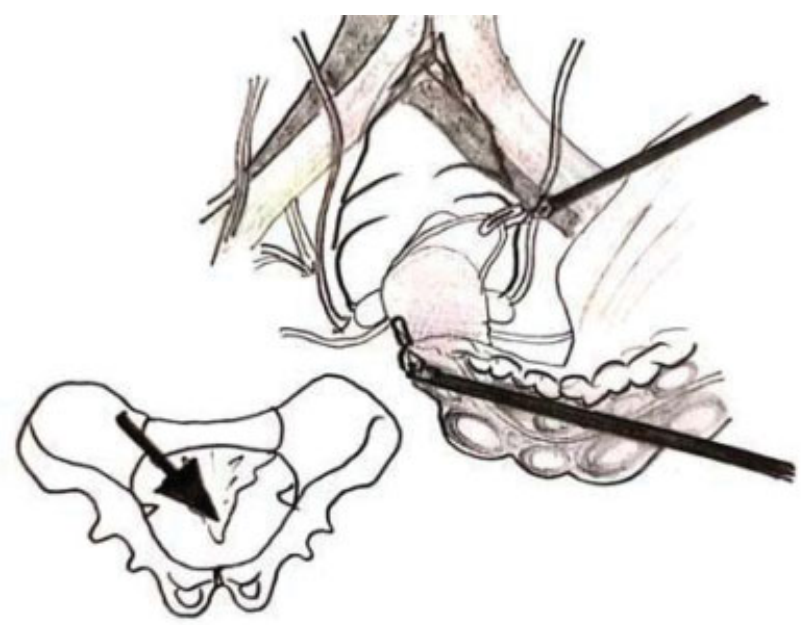

Fig. 7 Lateral pelvic dissection. 

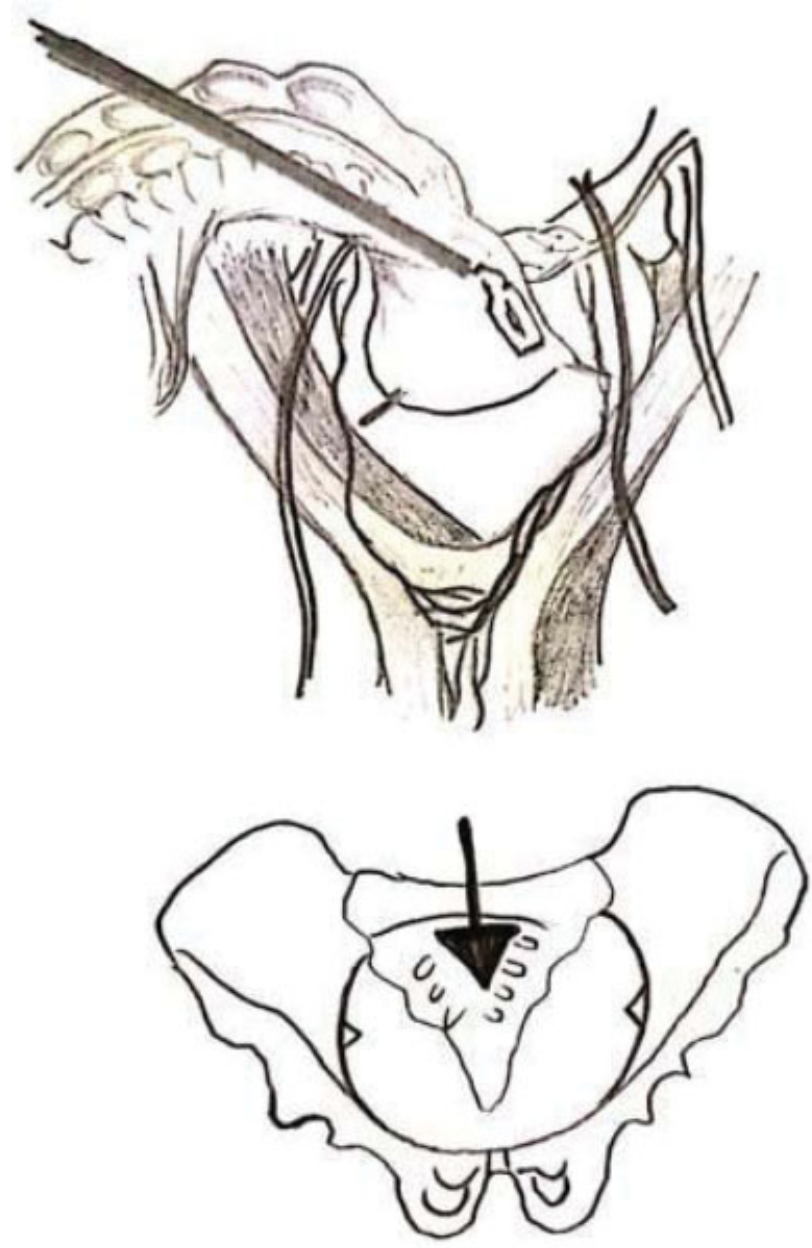

Fig. 8 Posterior pelvic dissection.

autonomic nerves and a meticulous surgical technique can prevent nerve damage.

\section{Conflict of Interests}

The authors have no conflict of interests to declare.

\section{References}

1 Milligan ETC, Morgan CN. Surgical anatomy of the anal canal: with special reference to anorectal fistulae. Lancet 1934;2 (5804):1150-1156

2 Parks AG. Pathogenesis and treatment of fistuila-in-ano. BMJ 1961;1(5224):463-469

3 Barleben A, Mills S. Anorectal anatomy and physiology. Surg Clin North Am 2010;90(01):1-15Table of Contents.
4 Sboarina A, Minicozzi A, Segattini C, et al. Shape and volume of internal anal sphincter showed by three-dimensional anorectal ultrasonography. Eur J Radiol 2012;81(07):1479-1482

5 Thomson WH. The nature of haemorrhoids. Br J Surg 1975;62 (07):542-552

6 Goligher JC, Leacock AG, Brossy JJ. The surgical anatomy of the anal canal. Br J Surg 1955;43(177):51-61

7 Bollard RC, Gardiner A, Lindow S, Phillips K, Duthie GS. Normal female anal sphincter: difficulties in interpretation explained. Dis Colon Rectum 2002;45(02):171-175

8 Hussain SM, Stoker J, Laméris JS. Anal sphincter complex: endoanal MR imaging of normal anatomy. Radiology 1995;197(03): 671-677

9 Wunderlich M, Swash M. The overlapping innervation of the two sides of the external anal sphincter by the pudendal nerves. J Neurol Sci 1983;59(01):97-109

10 Mittal RK, Bhargava V, Sheean G, Ledgerwood M, Sinha S. Pursestring morphology of external anal sphincter revealed by novel imaging techniques. Am J Physiol Gastrointest Liver Physiol 2014; 306(06):G505-G514

11 Corlieu A. Centenaire de la Faculte' de' Me'decine de Paris, 1794-1894. Paris: Imprimerie Nationale; 1896

12 Denonvilliers C-PD. Anatomie du perine'e. Bull Soc Anat Paris 1836;11:105-107

13 Richardson AC. The rectovaginal septum revisited: its relationship to rectocele and its importance in rectocele repair. Clin Obstet Gynecol 1993;36(04):976-983

14 Benchekroun A, Belahnech Z, Faik M, Marzouk M, Jelthi A. Une étiologie rarissime de tumeur rétro-vésico-prostatique: le mésothéliome kystique du péritoine. Prog Urol 1994;4(01):82-86

15 Heald RJ, Moran BJ. Embryology and anatomy of the rectum. Semin Surg Oncol 1998;15(02):66-71

16 Kinugasa Y, Niikura H, Murakami G, et al. Development of the human hypogastric nerve sheath with special reference to the topohistology between the nerve sheath and other prevertebral fascial structures. Clin Anat 2008;21(06):558-567

17 Havenga K, Enker WE. Autonomic nerve preserving total mesorectal excision. Surg Clin North Am 2002;82(05):1009-1018

18 Elliot Smith G. Studies in the anatomy of the pelvis, with special reference to the fasciae and visceral support. Part I. Anat Physiol 1908;42:252-270

19 Wesson MB. The development and surgical importance of the rectourethralis muscle and Denonvilliers' fascia. Urol 1922; 8:339-359

20 Wesson MB. Fasciae of the urogenital triangle. AMA 1923; 81:2024-2030

21 Tobin CE, Benjamin JA. Anatomical and surgical restudy of Denonvilliers' fascia. Surg Gynecol Obstet 1945;80:373-388

22 Nagpal K, Bennett N. Colorectal surgery and its impact on male sexual function. Curr Urol Rep 2013;14(04):279-284

23 Heald RJ, Ryall RD. Recurrence and survival after total mesorectal excision for rectal cancer. Lancet 1986;1(8496):1479-1482

24 Heald RJ, Moran BJ, Brown G, Daniels IR. Optimal total mesorectal excision for rectal cancer is by dissection in front of Denonvilliers' fascia. Br J Surg 2004;91(01):121-123 